\title{
JAMES E. FORD
}

\section{The Natural Alliance between Librarians and English Teachers in Course-Related Library Use Instruction}

\begin{abstract}
Significant advantages come from recognizing that course-related library use instruction should more accurately be thought of as research paper-related instruction. The English department is the primary locus of research paper instruction, and a recent survey reveals a much greater commitment to it than had been realized. Therefore, librarians should consider mounting an effort on several levels to create a special librarian-English teacher alliance. Furthermore, the structure of the writing curriculum offers an increasing potential for staged course-related library use instruction nationwide.
\end{abstract}

\section{BACKGROUND}

Even if there is generally agreement, as there seems to be, that course-related library use instruction is the ideal, the question remains: To which course or courses should bibliographic instruction be related? The easy answer is, of course, to all of them. However, as is well known, limited resources and the desire to create the best possible instructional program in the real world of today's colleges and universities require that priorities be established, choices made. The results of a recently completed national survey on research paper instruction in the undergraduate writing curriculum, conducted by this author and Dennis R. Perry in the winter of 1981 , suggest that library use instruction efforts should be primarily committed to the English department writing program in most institutions.

Librarians have not sufficiently acknowledged the degree to which the success of li-

James E. Ford is an assistant professor, Department of English, University of Nebraska-Lincoln. brary use instruction depends on the English writing program. Nor, similarly, have English teachers recognized the factors operating to make librarians their natural allies. John Lubans, Jr., recently conducted a survey of faculty members at the University of Houston's Downtown College that highlights this relationship. He asked, "Who is responsible for students learning library skills?" with the expectation, he says, that "librarians would be singled out as the most popular inculcators of library skills." $\mathrm{He}$ found, however, that English teachers were cited alone in 30 percent of the responses, with librarians 9 percent of the time, and with librarians and other educators 12 percent, for a total of 51 percent. Librarians were cited alone in only 9 percent of the responses, and when the times they were mentioned with others-most often English teachers - is added to that figure, the total is still only 37 percent. Admittedly, this is only one survey at one small school, but people who are familiar with attitudes on college campuses would not be surprised if this perception were common elsewhere. 
What is the reason for such a response? Lubans suggests that "As Ann Irving contends ... , library skills are not learned across the curriculum but are instead seen as things that can be taught separately. Since English classes are concerned with grammar and writing and research reports, the library skills responsibility quite naturally drifts into that department's bailiwick." ${ }^{2}$ Teachers in other subject areas are, in theory, and maybe even sometimes in practice, similarly situated. Nevertheless, English teachers are most likely to occupy one end of what is rightly viewed as one continuous research process, the other being occupied by librarians.

This process begins with the introduction of the assignment, includes all the steps in library research, and culminates in a written product. The general problem is that neither the English teacher nor the librarian is knowledgeable enough about the whole process. English teachers usually make pretty perfunctory gestures toward training students in some research methods, but their primary concern, naturally, is with the written results of the research. Librarians engaged in the library research segment of the process do not normally involve themselves at all in its other parts. The result is that teachers send students researching they know not what (or not well enough) - and librarians receive students from they know not where (or not well enough). Instead of this situation, in which the right hand knows not what the left is doing, teachers and librarians need to work in an extremely close relationship, each knowing to a considerable extent the responsibilities and capabilities of the other. Though the degree of knowledge will differ, both should know the nature of the assignment as well as the resources and methods available for its completion.

Ann Irving, recognizing in the article to which Lubans refers that this ideal complementary relationship has not generally existed, says that "teachers have been teaching content and not process while librarians have been teaching location and not usage., ${ }^{3}$ She goes on to describe a "properly integrated curriculum" that would approximate the ideal espoused by this author. Although she does not indicate what the teacher might do in the curriculum, she does make the radical suggestion that librarians "work back from existing assignments. ... One is simply to take an assignment or two and 'do' them, noting the steps, frustrations, and questions during the process." Extrapolating, the teacher should presumably work the other way, having in mind available research materials and methods when forming assignments. Obviously the entire research process and the students will benefit if teacher and librarian work dialectically together, each consulting and learning from the other.

Again, although this ideal relationship should no doubt exist between librarians and teachers in all subject fields, any working librarian can give some reasons why such a dream is not likely to come true. One of the most important reasons, one that this author has not seen put forward by librarians, is that not all subject areas require research papers, and some require them much less often than do others. When Irving speaks of content, process location, and usage, and when the complete research process is invoked here, it should be recognized that all these concepts most often become actual concerns in colleges and universities in the real-world context of the research paper.

Normally, course-related instruction is really research paper-related instruction, and the research paper is the special, though by no means exclusive, province of the English department. Not only do English teachers require more research papers than most teachers in other departments, but the responsibility for research paper instruction, per se, has most often devolved upon the English department. Whether English teachers like it or not-and some emphatically do not-this has already become one of their most important "service" functions for other departments.

\section{SuRvey Results}

Further, it is important that librarians understand the configuration this responsibility has taken in the English program. First, in schools across the country, freshman English is the only course required of virtually all students. A survey sponsored by the College English Association (CEA) in 1978 determined that freshman English is taught in 94.24 percent of schools, being required in 82.72 percent of them. ${ }^{5}$ The research paper instruction survey conducted at the University of Ne- 
braska found that instruction in the research paper is offered in 84.09 percent of freshman composition programs and is required in 78.11 percent of these programs. ${ }^{6}$

Therefore, freshman English offers librarians their only opportunity to reach virtually all students "where they are," when they are all in the same place - and when they have a felt need for research-related instruction. The CEA survey found that about 50 percent of freshman English programs constitute a two-semester sequence, and the author's survey reveals, not surprisingly, that research paper instruction is offered more than 50 percent of the time during the second semester only. However, it also occurs during both semesters at 15.17 percent of the institutions.

Few would have predicted these results indicating the ubiquitous nature of research paper instruction in English departments, but perhaps even more surprising is the degree of commitment to it, as revealed by the amount of time invested in the courses and the expenditure of faculty resources. Wherever it is offered at the freshman level, research paper instruction constitutes, on the average, a very considerable 34.66 percent of at least one course. (It should be kept in mind that the research paper often takes up from 50 to 100 percent of the second term of freshman English where two terms are offered.) This instruction is given by 55.76 percent of the regular faculty members in departments where it is offered, 77.22 percent of the total such instruction being offered by regular faculty members, and 29.30 percent of the average regular faculty member's load is devoted to it. The investment in instruction in the research paper is indeed high at the present time, and all indications are that it is increasing. Currently, there are plans to increase it in 7.08 percent of the programs and another 15.42 percent of the departments are engaged in discussions about revising the requirement. The freshman English program, therefore, offers the best opportunity for librarians to "relate" to a college course, especially for those who agree with Alan E. Erickson, whose library use instruction at Harvard is tied to the expository writing program, that " 'Concept, not detail' is the guiding principle."

There is a second feature of the English writing curriculum that should also interest those who recognize, with Carol F. Ahmed, that "on-demand lectures are profitable for faculty and students, as well as librarians, in order to meet a short-term but critical need. However, they can never substitute for a well-planned program of graduate[d] library instruction activities designed to reach students at all stages of their academic careers." $"$ In addition to freshman composition, advanced writing courses are now established in most schools across the country. No one has determined the exact percentage of institutions with advanced courses, but their growing prevalence is revealed in the CEA survey's finding that "the average for all schools is 3.53 other writing courses, with the range from 1 to 24 ."

The results of the University of Nebraska research paper survey join the findings of the CEA survey to suggest that, nationwide, the English writing curriculum is well planned, and staged course-related library use instruction is a growing possibility. Research paper instruction is also offered in 40.03 percent of all advanced composition programs and is required 42.35 percent of the time where it is offered. There are present plans to augment this offering in 7.78 percent of the departments, and 10 percent more are considering changing the requirement. Instruction in the research paper is available most often $(63.83$ percent) during the sophomore year, but it is also common ( 46.81 percent) during the junior year.

Where it is offered, research paper instruction on the advanced level is receiving a commitment similar to that on the freshman level. It entails an average 36.71 percent of at least one course and is taught by 40.01 percent of the regular faculty who are doing 70.62 percent of such teaching and who dedicate about 19.84 percent of their teaching loads to it.

It is clear from these findings that the English writing curriculum offers the only possibility of at least a two-stage course-related library instruction program in a very large, ever-increasing percentage of colleges and universities. This is not to say that librarians are not already involved in some way in these courses (how extensively will be shown below). But it is just as clear from reading the library use instruction literature that this involvement is now mostly either of the uncon- 
nected on-demand variety or it takes the form of generalized (not particularized) course-related orientation.

A unique feature of the research paper survey is that the final six questions sought to gauge the efforts that schools expend in helping students use library facilities for their research paper projects. The departments reported that some sort of library-related training is offered in support of the freshman composition curriculum at 76.09 percent of the schools and at 49.57 percent of schools with advanced writing courses. For about 87 percent of these at both levels this support comes at least partially in the form of an orientation tour of the library led by a librarian. Instead of or in addition to the tour, in most schools (65.91 percent, freshman; 69.23 percent, advanced) a librarian lectures in the library on materials and methods of using them. These lectures are delivered in the classroom (15.45 percent, freshman; 13.46 percent, advanced) or both the library and the classroom (25.45 percent, freshman; 15.38 percent, advanced) an average of 1.76 periods on the primary level and 1.83 on the advanced. Lectures by the teacher on library research methods also average 3.06 periods in freshman courses and 2.14 periods in the advanced writing curriculum. These lectures are most often held in the classroom, but also take place in the library itself $(21.47$ percent, freshman; 31.37 percent, advanced), or in both places (33.94 percent, freshman; 31.37 percent, advanced).

When asked whether their teachers and librarians received special training for the library-related support roles in the writing programs, 16.83 percent of the departments replied that only their teachers received such training for the freshman program, and 20.75 percent for the advanced courses. More (45.19 percent, freshman; 39.62 percent, advanced) indicated such training for librarians, and still more (50.48 percent, freshman; 56.60 percent, advanced) responded that in their institutions both teachers and librarians were trained in some way. Note, again, that these percentages of types of involvement relate to the 76.09 percent of departments receiving any sort of library use instruction in support of research paper programs on the freshman level and the 49 percent receiving it on the advanced level. A sig- nificant percent receive no such support at all, and others rely solely on the English faculty.

\section{Three Levels of Alliance}

If these thoughts and statistics have been at all persuasive, then the next step is to examine some possible ways of making actual an alliance that all must agree is presently only a potentiality. It seems that there are three levels on which attention might profitably be focused. There is the level of professional organizations, the level of individual schools, and the level of the individual teacher or librarian.

Librarians should know about three organizations that have assumed responsibility for the English writing curriculum. The oldest and largest is the Modern Language Association (MLA), which has within it two divisions that ought to be particularly concerned with research paper instruction. One of these, the Division on the Teaching of Writing, has never shown any interest in the subject. On the other hand, the Division of Methods of Literary Research, which already enrolls a significant number of librarians, sponsored a very successful program at the 1980 MLA convention. This program presented two librarians, Evan Farber and William Miller, and two English teachers addressing "Recent Developments in Research Paper Instruction." A similar session was held in 1981 in New York, and further research paper-related programs, which would include library-related concerns, may be sponsored by the division. Librarians could quite legitimately make their interests, along with their presence, felt at such programs, which have also, from time to time, been presented at the yearly Conference on Composition and Communication. The newest organization in this area is the Association for Advanced Composition. Librarians might consider, on the organizational level, seeking affiliate association status in these bodies. In the case of MLA, the affiliate is entitled to present its own program at the annual convention.

As individuals, librarians and English teachers have much to learn about each other's areas of expertise in the research process. This ignorance could be remedied in part through reading. Unfortunately, in spite of 
the extent to which the English profession is committed to research paper instruction in practice, it has not yet professionalized the subject; therefore, articles on it have been difficult to find. Fortunately, however, the first bibliography on the subject, a comprehensive annotated bibliography of periodical sources, has just been published. ${ }^{10}$ It covers all stages in the research process. In addition, librarians could benefit from reading in the major publications that focus on the writing curriculum. Some of the more important include College English, College Composition and Communication, and now, the Journal of Advanced Composition.

Recognizing that these suggestions make additional demands on the librarian's already tight budget of time, I nevertheless realize that results in these first two areas are much easier to achieve than at the middle level of the individual educational institution. For this third area requires that librarians and teachers work together in close cooperation, and both the personal experience of this author and reading in the library literature show that success here has been most difficult. Nor can blanket recommendations be made in this regard. Library periodicals do contain some sound advice and local examples of success.

\section{EXPERIMENT IN \\ Teacher-Librarian CoOperation}

Though this is not the place to describe it fully, some tentative suggestions based on a year-long experiment in teacher-librarian cooperation involving twenty sections of freshman English at a university that schedules one hundred sections per term, will be offered.

The experiment strengthened the conviction that it is essential that both teachers and librarians concern themselves, to differing degrees, with all aspects of the research process. For instance, reference tools were not taught by the librarians as discrete resources, but as stages in an overall strategy created with a particular assignment in mind. The librarian emphasized the usefulness of the LC catalogue as an aid in narrowing a research paper topic. General sources were presented as sources of specific kinds of information necessary in the early stages of the process, including universal and then specialized en- cyclopedias as sources of historical background information to put research in context, of important issues to be pursued, and of the names of authorities to be consulted further. Librarians became familiar with the program by attending all sessions taught in the classroom, and classroom teachers were present at all the sessions in the library.

The first written product to come out of this cooperation between teacher and librarian in the teaching of the research process was a background study that each student wrote to demonstrate awareness of each kind of information mentioned above-historical context, issues, terms, authorities-including, among other things, a bibliography citing examples of reference works falling within each category of reference work appearing on a general-to-specific research strategy model used to guide teachers and librarians in their presentations, as well as students in their actual research. ${ }^{11}$ The results of the experiment strengthened the belief that course-related instruction works best when a written product, even one so slight as a background study, serves as a concrete rationale and goal for the activity in the earlier stages of the research process.

A surprising feature of the experiment is that it takes only four class periods, including a demonstration of the research model in the library, to prepare students to produce the background study and, finally, a short research paper. The consensus so far is that the papers are at least as good as those written in previous years when most of a second semester of freshman English, which is no longer offered, was devoted to research paper instruction. Such a result would have been impossible without extremely close cooperation between and complementary knowledgeability of teachers and librarians.

The experimental unit began with a few willing participants in the two areas of the university, was confined to a manageable size, and has continued over a long enough time for adjustments to be made as the results have come in. Now it is possible to present for departmental scrutiny a demonstrably successful program. The final implementation is still a matter of department politics, but every possible effort has been made to increase the possibility of a favorable vote on the establishment of a special teacher- 


\section{4 / College \& Research Libraries • September 1982}

librarian alliance at one school. Perhaps if librarianship as a profession joins those on the English side in laying the groundwork on the levels of professional organizations and personal self-education, forging the alliance on the level that really matters-between English teachers and librarians in individual colleges and universities - will become much easier.

\section{REFERENCES}

1. John Lubans, Jr., "Let George Do It," $R Q$ 20:121 (Winter 1980).

2. Lubans, "Let George Do It," p.121.

3. Ann Irving, "Educating Users-Is There Really a New Approach?" RQ 20:12 (Fall 1980).

4. Irving, "Educating Users," p.13.

5. Claude Gibson, "The CEA 1978 National Survey of the Teaching of College Writing: Business as Usual: Write, Write, Write," The CEA Forum 9:37 (Oct. 1978).

6. James E. Ford and Dennis R. Perry, "Research Paper Instruction in the Undergraduate Writing Program: A National Survey," College English (in press). A random sample of 650 schools was chosen, of which 397 responded, for a most gratifying statistically significant return of 61.08 percent. The computer was programmed to analyze the results according to overall totals, sections of the country, and by types (four-year colleges and universities, junior and community colleges, technical schools) and sizes (very small $=$ less than 1,000 , small $=1,000-4,999$, medium $=$ $5,000-9,999$, large $=$ over 10,000$)$ of institutions.
7. Alan E. Erickson, comment, "Library Instruction" section, Journal of Academic Librarianship 6:41 (March 1980).

8. Carol F. Ahmed, comment, "Library Instruction" section, Journal of Academic Librarianship 6:97 (May 1980).

9. Gibson, "The CEA 1978 National Survey," p. 8.

10. James E. Ford, Sharla Rees, and David L. Ward, "Research Paper Instruction: Comprehensive Bibliography of Periodical Sources, 1929-1980," The Bulletin of Bibliography 39:84-98 (June 1982); a "Selected Bibliography on Research Paper Instruction" has appeared in Literary Research Newsletter 6:49-65 (Winter/Spring 1981).

11. The final results from the experimental research paper unit are being compiled for publication. The nature and use of the research strategy model as it was employed in the unit are explained in James E. Ford, "A General Research Model for Research Paper Instruction," Literary Research Newsletter 6:6-15 (Winter/Spring 1981). 